\title{
POTENSI PEMANFAATAN RUMPUT LAUT COKELAT CORONG (Turbinaria conoides) UNTUK MENGURANGI RESIKO KANKER TIROID PADA MANUSIA YANG TERPAPAR RADIASI IODIUM 131 AKIBAT KECELAKAAN NUKLIR FUKUSHIMA
}

Tando, J.M.

Fakultas Kedokteran Universitas Sam Ratulangi Manado (maggie.juwita@gmail.com)

\section{ABSTRAK}

Pemanfaatan zat radioaktif pada zaman modern ini berkembang dengan pesat, namun diiringi dengan ketakutan pada dampak yang timbul akibat kecelakaan atau kebocoran nuklir. Salah satu kecelakaan nuklir terbesar yang terjadi dalam abad ini adalah kecelakaan nuklir Fukushima yang terjadi di Jepang pada tanggal 11 Maret 2011. Iodium $131\left(1^{131}\right)$ ditemukan melimpah di awan uap radioaktif hasil kecelakaan nuklir tersebut. Ketika $1^{131}$ dilepaskan ke atmosfer, tiroid menyimpannya sebagai iodium non-radioaktif. $1^{131}$ yang menumpuk di kelenjar tiroid, memancarkan semburan radiasi yang dapat merusak DNA dan materi genetik lainnya. Kerusakan tersebut menghapus batasan normal untuk pertumbuhan sel dan pembelahan sehingga terjadi pertumbuhan tidak terkendali. Pada kanker tiroid, radiasi mengaktifkan komponen dari jalur MAPK terutama melalui inversi paracentric kromosom. Sebuah metode pengobatan yang umum untuk mencegah eksposur $\mathrm{I}^{131}$ adalah dengan menjenuhkan tiroid secara regular dengan non-radioaktif $f^{127}$. Ada alasan untuk berhati-hati dalam penggunaan kalium iodide atau suplemen yodium, karena penggunaan jangka panjang dapat menyebabkan kondisi seperti fenomena Jod-Basedow, efek Wolff-Chaikoff, memperburuk hipertiroid dan hipotiroid. Untuk itulah diperlukan adanya konsumsi iodium non radioaktif yang berasal dari unsur alami. Salah satu bahan yang dapat dikonsumsi yaitu Turbinaria conoides yang dikenal dimasyarakat Indonesia dengan rumput laut coklat corong.

Kata kunci : radiasi, kanker tiroid, Turbinaria conoides

\section{PENDAHULUAN}

Perkembangan pemanfaatan zat radioaktif pada zaman modern ini sangat berkembang dengan pesat seiring dengan pertumbuhan dan perkembangan teknologi dalam pemanfaatannya. Kecelakaan nuklir atau kebocoran nuklir adalah hal yang paling ditakutkan dibalik manfaaat energi nuklir bagi manusia. Kecelakaan nuklir ini memiliki dampak jangka pendek dan jangka panjang yang berbahaya bagi manusia. Dampak kesehatan, ekonomi, sosial dan psikologis dapat terjadi bagi manusia yang tertimpa. Sebenarnya mekanisme pertahan tubuh manusia dapat melindungi diri dari kerusakan sel akibat radiasi maupun pejanan zat kimia berbahaya lainnya. Namun radiasi pada jumlah tertentu tidak bisa ditoleransi oleh mekanisme pertahanan tubuh itu. Proses ionisasi pada sel-sel tubuh karena proses radiasi dapat merusak sel-sel dan organ tubuh yang menimbulkan berbagai manifestasi. Kanker tiroid adalah jenis yang paling umum dari tumor padat manusia yang terkait dengan paparan radiasi eksternal pengion, terutama jika terjadi pada neonatus, bayi dan anak. ${ }^{(1,2)}$

Dalam catatan sejarah manusia terdapat kejadian kecelakan nuklir terbesar di dunia di antaranya adalah kecelakaan Chernobyl, Three Mile Island Amerika dan di Fukushima Jepang. ${ }^{(2)}$ Kecelakaan nuklir Fukushima di Jepang yang berlangsung sejak tanggal 11 Maret 2011 masih menyisakan potensi bahaya baik bagi penduduk yang berada disekitar Fukushima maupun bagi penduduk yang berada jauh dari wilayah Fukushima bahkan dapat melewati batas negara. Hal ini terjadi karena bahan radioaktif yang terlepas dari instalasi PLTN masuk ke udara dan membentuk awan radioaktif yang mengikuti arah angin. Awan radioaktif ini akhirnya akan turun ke permukaan bumi sehingga 
dapat mengkontaminasi benda-benda di permukaan bumi termasuk manusia. ${ }^{(3)}$

Gempa bumi dan tsunami yang terjadi pada tanggal 11 Maret 2011 di daerah Tohoku, Jepang telah menyebabkan tiga reaktor nuklir di Fukushima meledak dan sebagian meleleh. Kecelakaan yang buruk pada reaktor nuklir telah menyebabkan kontaminasi yang sangat serius pada lingkungan. Tingkat radiasi pada reaktor nuklir nomor 1 di Fukushima telah mencapai $1,000 \mathrm{mSv} / \mathrm{jam}$ (millisievert/jam). Pada pertengahan Agustus 2011, emisi radiaktif lodine dan Cesium dari Reaktor nuklir I Fukushima telah mendekati level radiasi bencana Chernobyl pada tahun 1986. Hasil survey yang dilaporkan oleh Japanese Ministry of Science and Education menunjukkan bahwa daerah yang berada di area $12 \mathrm{mil}(19 \mathrm{~km})$ radius zona evakuasi dari Fukushima telah terkontaminasi berat oleh radionuklida ${ }^{\cdot(2,3)}$

Salah satu zat yang paling melimpah di awan uap radioaktif hasil kecelakaan pembangkit listrik tenaga listrik Fukushima adalah lodium 131 yang merupakan bentuk radioaktif dari elemen iodium yang dapat ditemukan di seluruh alam. Iodium 131 menimbulkan resiko kesehatan khususnya efeknya pada kelenjar tiroid yaitu memicu terjadinya kanker tiroid. $^{(3)}$

\section{METODE PENULISAN}

Penulisan bersifat deskriptif dengan bahanbahan yang digunakan adalah artikel dari majalah dan jurnal, makalah ilmiah, buku ajar, dan data-data sekunder yang telah ada sebelumnya yang merupakan hasil penelitian peneliti sebelumnya. Setelah menemukan masalah yang akan dikaji, buku/literatur/makalah ilmiah dan berbagai informasi yang berhubungan dengan topik dikumpulkan dan dipelajari. Teori - teori dan data sekunder yang ada dirangkum dan dianalisis serta disentesis untuk kemudian disusun sebagai naskah deskriptif.

\section{ANALISIS DAN SINTESIS}

\section{Paparan Radiasi}

Paparan radiasi terdiri atas paparan radiasi eksterna dan paparan radiasi interna. Perbedaan karakteristik dari kedua jenis paparan harus dipertimbangan ketika memperkirakan kemungkinan terjadinya efek pada tubuh dari pola radiasi yang berbeda. Dengan terdepositnya sebuah radionuklida dalam tubuh, dosis radiasi yang mengenai berbagai organ dan jaringan tubuh terus terakumulasi sampai radionuklida tersebut dieliminasi dengan proses fisik atau biologi. ${ }^{(4)}$

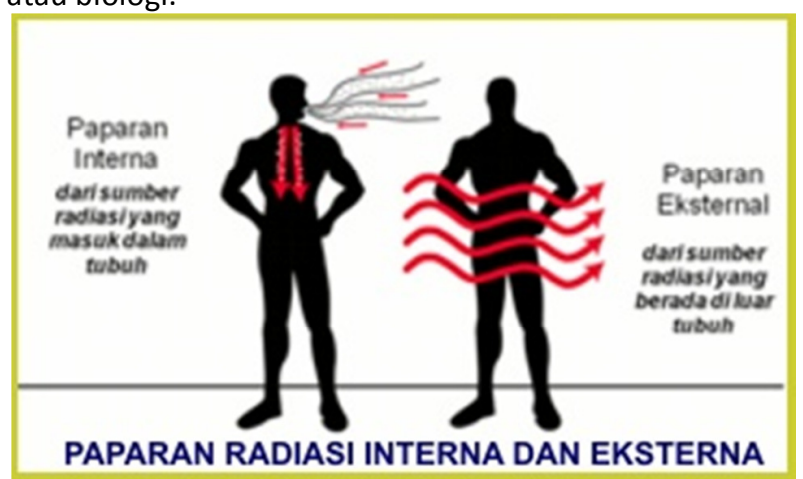

Gambar 1. Paparan radiasi interna dan eksterna

Paparan radiasi eksterna merupakan paparan yang terjadi bila ada jarak antara sumber radiasi dengan individu terpapar. Beberapa faktor yang berpengaruh terhadap tingkat keparahan kerusakan akibat paparan eksterna, antara lain adalah jenis radiasi, dosis serap, distribusi penyinaran pada tubuh, distribusi waktu penyinaran (dosis tunggal atau terbagi/fraksinasi) dan usia.$^{(5)}$

Paparan radiasi interna terjadi bila tidak ada jarak antara sumber radiasi dengan individu terpajan, sehingga sering diistilahkan sebagai kontaminasi. Kontaminasi pada manusia dapat terjadi secara eksterna atau secara interna dengan bahaya dan efek yang ditimbulkan beraneka ragam. Kontaminasi eksterna terjadi apabila radionuklida menempel pada bagian luar tubuh, sedangkan kontaminasi interna terjadi apabila bahan radionuklida masuk ke dalam tubuh melalui jalur pernapasan (inhalasi), penelanan (ingesi) atau penyerapan melalui kulit terbuka maupun kulit yang utuh (untuk $\mathrm{H}^{3}$ ). Dengan demikian individu yang terkontaminasi eksterna dapat pula terkontaminasi interna. $^{(4,5)}$

Tahapan berlangsungnya kontaminasi interna adalah (1) masuk tubuh melalui jalan masuk, (2) penyerapan ke dalam darah atau cairan getah bening, (3) distribusi ke seluruh tubuh dan akumulasi pada organ sasaran, dan (4) pengeluaran melalui urin, feses atau keringat. ${ }^{(5)}$ 


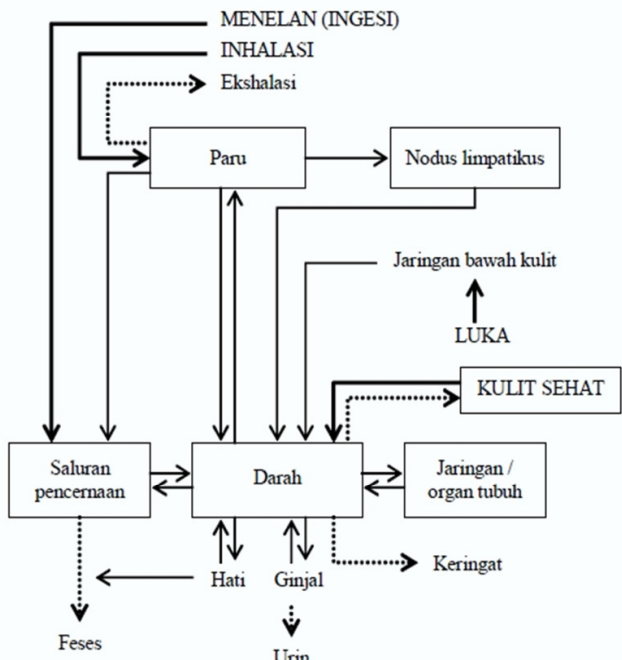

Gambar 2. Diagram kinetika radionuklida dalam tubuh: masukan, distribusi dan ekskresi radionuklida.

Paparan radiasi pada organ tubuh secara bertahap akan mengalami perubahan laju dosis dengan bertambahnya waktu. Selain itu irradiasi dari radionuklida ini umumnya terjadi secara tidak merata pada organ dan jaringan target dan sekitarnya. $^{(5)}$

Dari data yang diperoleh dari Kitaibaraki sekitar 75 kilometer selatan dari pabrik nuklir Fukushima, Jepang, dapat dilihat tebaran radiasi pada makanan :

\begin{tabular}{|l|l|l|}
\hline No. & Makanan : & Kadar lodium 131 \\
\hline 1. & $\begin{array}{l}\text { Wasabi (Lobak } \\
\text { Jepang) }\end{array}$ & $2500 \mathrm{~Bq} / \mathrm{kg}$ \\
\hline 2. & Ketimun & $14 \mathrm{~Bq} / \mathrm{kg}$ \\
\hline 3. & $\begin{array}{l}\text { Chysanteum } \\
\text { (Shugiku) }\end{array}$ & $623,9 \mathrm{~Bq} / \mathrm{kg}$ \\
\hline 4. & Sawi Hijau (Mizuna) & $630 \mathrm{~Bq} / \mathrm{kg}$ \\
\hline 5. & Daun bawang & $64 \mathrm{~Bq} / \mathrm{kg}$ \\
\hline 6. & Bayam & $54.000 \mathrm{~Bq} / \mathrm{kg}$ \\
\hline 7. & Susu & $1.510 \mathrm{~Bq} / \mathrm{kg}$ \\
\hline
\end{tabular}

Tabel 1. Tebaran radiasi Fukushima

Jalur paparan signifikan pada kesehatan masyarakat adalah deposisi dari $1^{131}$ pada rumput dan tanaman hijau yang kemudian dikonsumsi oleh sapi atau kambing. Manusia dapat terkontaminasi setelah mengkonsumsi produk susu segar dari sapi atau kambing tersebut. Paparan terjadi segera untuk orang-orang yang berada di sekitar tempat radiasi nuklir dihasilkan dan berada di udara.
Pajanan internal terjadi dengan menghidup $I^{131}$ yang berada di udara tersebut. Selain itu dengan mengkonsumsi makanan yang telah terkontaminasi zat radioaktif tersebut. Jalur oral adalah jalur utama paparan radiasi internal dari $1^{131}$. Asupan yodium sebelum paparan ini penting karena dengan kekurangan yodium maka akan terjadi peningkatan penyerapan oleh tiroid. Setelah paparan penting untuk mengetahui informasi tentang jumlah dan jenis kandungan $1^{131}$ dari produk susu yang dikonsumsi ${ }^{(3,5)}$

Jika pangan yang terkontaminasi zat radioaktif dikonsumsi manusia, jumlah paparan zat radioaktif dalam tubuh manusia akan semakin bertambah. Sebenarnya, secara alami tubuh manusia mengandung zat radioaktif dan terpapar banyak radiasi, baik dari alam maupun makanan dan minuman yang dikonsumsi sehari-hari. ${ }^{(3)}$

Semakin besar paparan zat radioaktif, semakin besar peluang munculnya radikal bebas yang memicu kanker. lodium 131 menyerang kelenjar tiroid, dan memicu kanker tiroid. ${ }^{(6)}$

Diperkirakan dosis radiasi dari $1^{131}$ baik terhadap tiroid maupun seluruh tubuh melibatkan proses inhalasi atau injesti dengan usia tertentu. Konsentrasi iodium rata-rata dalam udara, laju pernafasan, dan waktu pemaparan mempengaruhi paparan radiasi secara inhalasi. Sedangkan pemaparan lewat proses ingesti ditentukan oleh konsentrasi rata-rata ${ }^{131}$ di dalam makanan dan air dan jumlah yang dikonsumsi. Konsentrasi tersebut tergantung jarak waktu proses produksi dan konsumsi serta pola geografis konsentrasi udara dan distribusinya. Menurut Reservasi Nuklir Handford, seorang anak memiki dosis penggunaan hormone tiroid hingga 20 kali dari orang dewasa. Anak-anak yang tinggal di daerah paparan maksimum diperkirakan telah menerima dosis 10 kali lebih banyak dibandingkan orang dewasa pada periode waktu yang sama. ${ }^{(6,7)}$

Faktor-faktor yang mempengaruhi dosis kontaminasi internal tiroid yang disebabkan akibat mengkonsumsi produk susu adalah :

1. Waktu antara produksi dan konsumsi.

Karena memiliki waktu paruh yang singkat, penundaan waktu komsumsi yang disebabkan oleh pengolahan dan transportasi susu dapat menurunkan radioaktivitas lodium didalam susu. Faktor ini memainkan peran penting 
dalam penelitian terakhir dan tergantung dari apakah populasi yang mengkonsumsi terletak diperkotaan atau dipedesaan. Pada umumnya, populasi perkotaan menggunakan olahan susu pabrik sedangkan penduduk desa mengkonsumsi susu segar yang belum diproses.

2. Tingkat konsumsi susu segar atau produk susu seperti keju.

Susu kambing dan domba memiliki konsentrasi tertinggi kontaminasi $I^{131}$.

3. Umur dan jenis kelamin kelompok terpapar.

Umur pada saat terpapar merupakan terpenting yang mempengaruhi konsentrasi terkontaminasinya $\mathrm{I}^{131}$ dalam tubuh. Anakanak membutuhkan lebih banyak tiroid dibandingkan dewasa sehingga kemungkinan terkontaminasi radiasi lebih besar. Setelah usia 50, massa tiroid dan kapasitas pengambilan yodium berkurang secara bertahap.

4. Distribusi geografis dari populasi berkaitan dengan yang mempengaruhi dosis radiasi $I^{131} \cdot(4,6,7)$

\section{Radiasi lodium 131 dan Kanker Tiroid}

Tubuh manusia menyerap iodium dan menyimpannya dalam kelenjar tiroid. Ketika lodium 131 dilepaskan ke atmosfer, tiroid menyimpannya sebagai alami iodium, non-radioaktif. Iodium 131 menumpuk di kelenjar tiroid, memancarkan semburan radiasi yang dapat merusak DNA dan materi genetik lainnya. Kerusakan tersebut dapat menghapus batas-batas normal untuk pertumbuhan sel dan pembelahan. Pertumbuhan tidak terkendali jaringan tiroid adalah kanker tiroid. ${ }^{(8)}$

Radiasi menyebabkan efek kesehatan ketika sel-sel yang cukup baik mengalami kematian cukup cepat sehingga mengganggu fungsi jaringan, atau sel mengalami kerusakan tidak sempuna lalu kemudian bermutasi menjadi karsinogenik. ${ }^{(1)}$ Paparan terhadap kelenjar tiroid dari dosis sedang sampai dosis tinggi (6,5 hingga 2.000 centigray) dari $1^{131}$ secara linear meningkatkan resiko untuk kanker tiroid. Penyakit ini terjadi pada sekitar $20 \%$ orang tapi mungkin tidak terlihat hingga 30 tahun setelah paparan awal. Wanita memiliki lebih besar kemungkinan untuk terkena kanker tiroid dibandingkan pria (2:1) dan anak-anak memiliki resiko lebih besar dibandingkan orang dewasa $(8: 1) .(4,6)$

Sekitar 1.800 kasus kanker tiroid dilaporkan terjadi dari kecelakaan pembangkit listrik nuklir
Chernobyl. Hasil ini lebih tinggi dibandingkan yang diharapkan karena asupan diet rendah yodium pada masyarakat dan daerahnya endemik gondok. ${ }^{(6)}$

Interaksi radiasi dengan DNA dapat menyebabkan terjadinya perubahan struktur molekul gula atau basa, putusnya ikatan hydrogen antar basa, hilangnya basa dan lainnya. Kerusakan yang lebih parah adalah putusnya salah satu untai DNA yang disebut single strand break, atau putusnya kedua untai DNA yang disebut double strand breaks. Secara alamiah sel mempunyai kemampuan untuk melakukan proses perbaikan terhadap kerusakan yang timbul dengan menggunakan beberapa jenis enzim yang spesifik. Proses perbaikan dapat berlangsung terhadap kerusakan yang terjadi tanpa kesalahan sehingga struktur DNA kembali seperti semual dan tidak menimbulkan perubahan struktur pada sel. Tetapi dalam kondisi tertentu, proses perbaikan tidak berjalan sebagai mana mestinya sehingga walaupun kerusakan dapat diperbaiki, tetapi tidak sempurna sehingga menghasilkan DNA yang berbeda, yang dikenal dengan mutasi.

Kerusakan yang terjadi pada DNA dan kromosom sel sangat bergantung pada proses perbaikan yang berlangsung. Bila proses perbaikan berlangsung dengan baik/sempurna, dan juga tingkat kerusakan sel tidak terlalu parah, maka sel bisa kembali normal. Bila perbaikan sel tidak sempurna, sel tetap hidup tetapi mengalami perubahan. Bila tingkat kerusakan sel sangat parah atau perbaikan tidak berlangsung dengan baik, maka sel akan mati. Sel yang paling sensitive terhadap pengaruh radiasi adalah sel yang paling aktif melakukan pembelahan dan tingkat differensiasi (perkembangan/ kematangan sel) rendah. Sedangkan sel yang tidak mudah rusak akibat pengaruh radiasi adalah sel dengan tingkat differensiasi yang tinggi. ${ }^{(6-8)}$

Dosis tinggi radiasi pengion menghasilkan kerusakan pada objek biologi menginduksi kematian sel. Sebaliknya, dosis rendah menginduksi terutama banyak istirahat DNA untai ganda, penghapusan, mutasi titik dan / atau ketidakstabilan kromosom ${ }^{(9)}$ Pada karsinoma tiroid papiler, mutasi gen coding untuk efektor sepanjang jalur MAPK merupakan pusat untuk transformasi. Mutasi titik BRAF paling sering terjadi pada tumor sporadic, sebaliknya pada tumor akibat radiasi terjadi inverse paracentric yang mengaktifkan reseptor tirosin kinase RET dan NTRK1. Dilaporkan bahwa penyusunan kembali BRAF melalui 
paracentric dari kromosom 7q mengakibatkan fusi di-frame antara ekson 1-8 dari gen AKAP9 dan ekson 9-18 dari BRAF. Protein fusi berisi domain protein kinase dan tidak memiliki bagian $\mathrm{N}$-terminal dari autoinhibitory BRAF. Protein ini memiliki aktivitas kinase tinggi dan mengubah NIH3T3 sel. Perpaduan AKAP9-BRAF itu ditemukan pada perkembangan karsinoma tiroid papiler setelah pemaparan pendek, sedangkan BRAF mutasi titik tidak hadir dalam kelompok ini. ${ }^{(10)}$ Data ini menunjukkan bahwa pada kanker tiroid, radiasi mengaktifkan komponen dari jalur MAPK terutama melalui paracentric kromosom, sedangkan dalam dari penyakit, efektor sepanjang jalur yang sama diaktifkan secara dominan oleh mutasi titik. ${ }^{(9,11)}$

Pada analisis gen ditemukan fusi antara RET yang terletak di kromosom 10q11.2 dan gen lain yang secara spesifik ditemukan pada kanker kelenjar tiroid. Hal ini secara kolektif disebut penyusunan ulang RET/PTC dan mewakili gen chimeric. Di antara 16 jenis RET / PTC, RET/PTC1 dan RET/PTC3 adalah varian yang paling umum dan terdapat sekitar $90 \%$ dari semua gen chimeric ${ }^{(12) .}$ Prevalensi penyusunan ulang RET/PTC3 berkisar dari $11 \%$ menjadi $43 \%$ pada kanker tiroid papiler dan $50-80 \%$ pada pasien dengan riwayat paparan radiasi. ${ }^{(13)}$ Namun, prevailance tinggi semua RET / PTC penyusunan ulang adalah karakteristik dari kanker papiler pada pasien muda dan tidak spesifik untuk iradiasi. Tipe lain dari penataan ulang gen, AKAP9-BRAF fusi, telah ditemukan di $11 \%$ dari kanker tiroid onset awal papiler tetapi $0 \%$ dari tumor dengan latency lagi setelah kecelakaan. ${ }^{(14)}$

\section{Mengurangi resiko kanker tiroid dengan rumput laut coklat corong (Turbinaria conoides)}

Sebuah metode pengobatan yang umum untuk mencegah eksposur $1^{131}$ adalah dengan menjenuhkan tiroid secara regular dengan nonradioaktif ${ }^{127}$. Ada alasan untuk berhati-hati dalam penggunaan kalium iodide atau suplemen yodium, karena penggunaan jangka panjang dapat menyebabkan kondisi seperti fenomena JodBasedow, efek Wolff-Chaikoff, memperburuk hipertiroid dan hipotiroid. Untuk itulah diperlukan adanya konsumsi iodium non radioaktif yang berasal dari unsur alami. Salah satu bahan yang dapat dikonsumsi yaitu Turbinaria conoides yang dikenal dimasyarakat Indonesia dengan rumput laut coklat corong.
Turbinaria conoides memiliki batang silindris, tegak, kasar dan memiliki tinggi mencapai $75 \mathrm{~cm}$. (15,16) Bentuk daun menggasing, melebar hingga distal akhir, dan membentuk batas helaian mahkota melalui baris sisi. ${ }^{(16)}$ Warna thalli coklat muda atau coklat tua. Umumnya terdapat di daerah rataan terumbu, menempel pada batu dan tersebar luas di Asia Tenggara khususnya Indonesia. ${ }^{(15-17)}$ Tumbuhan ini berpotensi ekspor ke Jepang. ${ }^{(17)}$ Berdasarkan taksonominya termasuk dalam domain Eukaryota, kingdom Chromista, subkingdom Chromobiota, infra kingdom Heterokonta, filum Ochrophyta, subfilum Phaeista, infrafilum Chrysista, superkelas Phaeistia, kelas Phaeophyceae, ordo Fucales, marga Sargassaceae, genus Turbinaria, spesies Turbinaria conoides.

\begin{tabular}{|l|l|}
\multicolumn{1}{|c|}{ Jenis } & \multicolumn{1}{|c|}{ Daerah Penyebaran } \\
\hline Dictyota dichotoma & $\begin{array}{l}\text { Kep. Seribu, Sulawesi, P. Komodo, } \\
\text { Kep. Kangean, Bali. }\end{array}$ \\
\hline Hormophysa sp & Sumatera Utara \\
\hline Hydroclathrus clathatus & $\begin{array}{l}\text { Jawa, Kalimantan, Sulawesi, Timor, } \\
\text { Sumbawa, Kep. Seribu. }\end{array}$ \\
\hline Padina australis & $\begin{array}{l}\text { Jawa, Sumatera, Ambon, Sumba, } \\
\text { Sulawesi, Timor, Sumbawa, Kep. } \\
\text { Seribu. }\end{array}$ \\
\hline Sargassum sp. & $\begin{array}{l}\text { Jawa, Sulawesi, P. Kei, Sumatera } \\
\text { Utara, Lombok, Kep. Aru, Irian }\end{array}$ \\
\hline Turbinaria conoides & Jawa, Sumatera, Irian, Maluku, Flores \\
\hline
\end{tabular}

Tabel 2. Penyebaran alga coklat di Indonesia

Pada tabel 2, terlihat jelas bahwa Turbinaria conoides mendominasi distribusi hampir di seluruh perairan Indonesia. Namun demikian pemanfaatannya masih sangat terbatas, bahkan sebaliknya sering dianggap sebagai sampah laut pada musim tertentu, sebab banyak yang hanyut di permukaan laut dan terdampar di pantai akibat tercabut atau patah akibat ombak yang besar atau karena perubahan musim. ${ }^{(20)}$

Medical State Techinal Medicine Centre Rusia menyatakan bahwa Turbinaria sp aman untuk dikonsumsi dan tidak menimbulkan efek negatif pada organ.

Turbinaria conoides dapat dijadikan tepung rumput laut yang mengandung yodium hayati dalam bentuk tepung rumput laut pada produk mie, dengan kandungan yodium yang cukup tinggi sebagai bahan makanan untuk kesehatan. Produk 
mie yang diberi tepung yodium dapat dicirikan sebagai warna yang tampak keunguan.

Turbinaria conoides yang ada juga, dapat diolah menjadi makanan yang siap untuk dikonsumsi dalam bentuk yang sederhana namun mengandung tinggi iodium, seperti selai dan dodol. Berikut adalah jumlah kandungan iodium didalam selai dan dodol :

\begin{tabular}{|c|c|c|c|c|c|}
\hline \multirow{2}{*}{$\begin{array}{l}\text { Produ } \\
k\end{array}$} & \multirow{2}{*}{$\begin{array}{l}\text { lodiu } \\
\text { m } \\
\text { ug/g }\end{array}$} & \multirow{2}{*}{$\begin{array}{l}\text { AK } \\
\text { G } \\
\text { ug/ } \\
\text { g }\end{array}$} & \multirow{2}{*}{$\begin{array}{l}\text { Konsum } \\
\text { si }\end{array}$} & \multirow{2}{*}{$\begin{array}{l}\text { Suplai } \\
\text { iodium } \\
\text { per } \\
\text { konsum } \\
\text { si }\end{array}$} & AKG \\
\hline & & & & & (\%) \\
\hline Selai & 17,79 & 150 & $\begin{array}{l}8 \mathrm{~g} \text { per } \\
\text { potong } \\
\text { roti }\end{array}$ & $\begin{array}{l}142,32 \\
\text { ug }\end{array}$ & $\begin{array}{l}94,8 \\
8\end{array}$ \\
\hline Dodol & 19,57 & 150 & $\begin{array}{l}15 \mathrm{~g} \text { per } \\
\text { buah }\end{array}$ & $\begin{array}{l}293,55 \\
\text { ug }\end{array}$ & $\begin{array}{l}195, \\
7\end{array}$ \\
\hline
\end{tabular}

Tabel 4. Kandungan iodium dalam selai dan dodol

Angka Kecukupan Gizi iodium rata-rata yang dianjurkan per orang per hari untuk remaja mulai 10 tahun hingga orang dewasa lebih dari 60 tahun adalah $150 \mathrm{mg} /$ hari, maka sumbangan iodium dari satu kerat roti yang diolesi selai sebanyak kurang lebih satu sendok makan (8 g) dapat memenuhi $94.88 \%$ AKG. Sedangkan pada dodol dengan mengkonsumsi satu buah dodol (15 g) dapat memenuhi 195.7 \% AKG. Berdasarkan data tersebut dapat diketahui bahwa konsumsi selai dan dodol rumput laut secara nyata dapat membantu mencukupi kebutuhan iodium bagi tubuh. ${ }^{(22)}$

\section{SIMPULAN}

Berdasarkan data yang telah dianalisis dan disintesis dapat disimpulkan bahwa :

1. Kecelakaan nuklir Fukushima memberikan kontribusi yang besar dalam kanker tiroid akibat radiasi yaitu melalui inversi paracentric kromosom pada jalur MPAK.

2. Turbinaria conoides yang ditemukan melimpah di Indonesia namun belum dimanfaatkan dapat digunakan untuk menjenuhkan tiroid secara regular sehingga mengurangi resiko eksposur $1^{131}$ pada kecelakaan nuklir.

\section{DAFTAR PUSTAKA}

1. Ron E, Lubin JH, Shore RE et al. Thyroid cancer after exposure to external radiation; a pooled analysis of seven studies. Radiat Res 141: 256277, 1995

2. WHO. 2011. IONIZING RADIATION, HEALTH EFFECTS AND PROTECTIVE MEASURES. Available at http://www.who.int/ionizing_radiation/a_e/en/ . Access on : October 27, 2011

3. Wikipedia. 2011. Radiation Effects from Fukushima Daiichi Nuclear Disaster. Available at http://en.wikipedia.org/wiki/Radiation_effects_ from_Fukushima_Daiichi_nuclear_disaster . Access on : October 27, 2011.

4. Boyce, J. 2005. Editorial : Radiation-induced Thyroid Cancer - What's New. Journal of the National Cancer Institute, Vol. 97

5. Skerrett, P.J. 2011. Tyroid. Harvard Health Publication. Harvard Medical School. Available at

http://www.health.harvard.edu/blog/thyroidcancer-a-hazard-from-radioactive-iodineemitted-by-japans-failing-nuclear-power-plants201103141867/thyroid. Access on : October 27, 2011

6. American Thyroid Association. 2005. Radioactive lodine Use for Thyroid Diseases. American Thyroid Association. United States

7. National Council on Radiation Protection and Measurements. Induction of thyroid cancer by ionizing radiation. NCRP Report No. 80. Bethesda (MD): National Council on Radiation Protection and Measurements; 1985

8. NCCN Clinical Practice Guidelines in Oncology. 2006. Thyroid Carcinoma. Version 2. National Comprehensive Cancer Network, Inc. Available at : www.nccn.org. Access on : October 19, 2011

9. Ciampi R, Knauf JA, Kerler $R$ et al. 2005. Oncogenic AKAP9-BRAF fusion is a novel mechanism of MAPK pathway activation in thyroid cancer. Available at http://www.ncbi.nlm.nih.gov/pubmed/15630448 . Access on : October 23, 2011

10. Detours V, Wattel S, Venet $D$, et al. Absence of a specific radiation signature in post-Chernobyl thyroid cancers. British J Cancer 92: 1545-1552, 2005

11. Yamashita, S. 2009. CHERNOBYL BEYOND 20 YEARS AND THYROID CANCER. Department of International Health and Radiation Research and Molecular Medicine, Atomic Bomb Disease Institute. Nagasaki University Graduate School of Biomedical Sciences. Japan. Available at 
http://www.hotthyroidology.com/editorial_158. html. Access on : October 19, 2011

12. Kodama $Y$, Asai N, Kawai K, Jijiwa M, Murakumo $Y$, Ichihara M, Takahashi M. The RET protoongogene: a molecular therapeutic target in thyroid cancer. Cancer Sci 96: 143-148, 2005

13. Rabes $H$, Demidchik EP, Sidorov JD, Lengfelder $E$, Beimfohr C, Hoelzel D, Klugbauer S. Pattern of radiation-induced RET and NTRK1 rearrangements in 191 post-Chernobyl papillary thyroid carcinomas: biological, phenotypic and clinical implication. Clin Cancer Res 6: $1093-$ 1103, 2000

14. Ciampi R, Knauf JA, Kerier $R$ et al. Oncogenic AKFPO-BRAF fusion is a novel mechanism of MAPK pathway activation in thyroid cancer. J Clin Invest 115: 94-101, 2005

15. IPTEKNET. 2002. Turbinaria conoides. Available at

http://www.iptek.net.id/ind/pd_alga/index.ph $\mathrm{p} ? \mathrm{mnu}=2 \&$ alga $=$ coklat\&id $=17$. Access on October 27, 2011

16. PROHATI. 2011. Turbinaria. Available at http://www.proseanet.org/prohati2/browser.p hp?docsid=326. Access on October 27, 2011

17. Zipcodezoo. 2011. Turbinaria conoides . Available http://zipcodezoo.com/Chromista/T/Turbinaria _conoides/ . Access on October 27, 2011

18. Coremap. 2011. Program Rehabilitasi dan Pengelolaan Terumbu Karang. Available at http://www.coremap.or.id/datin/seaweed/ind ex.php?keyid=57\&act=detail . Access on October 27, 2011.

19. Winarno, F.G. 1990. Teknologi Pengolahan Rumput Laut. Sinar Pustaka Harapan. Jakarta.

20. MS, Sulistijo. 2002. Penelitian Budidaya Rumput Laut di Indonesia. LIPI. Jakarta.

21. Wirjatmadi, B., M. Adriani dan S. Purwanti. 2002. Pemanfaatan Rumput Laut (Eucheuma cottonii) Dalam Meningkatkan Nilai Kandungan Serat Dan Yodium Tepung Terigu Dalam Pembuatan Mi Basah. Jurnal Penelitian Medika Eksakta Vol. 3 No. 1 April 2002: 89-104. Universitas Airlangga. Surabaya

22. Winarno, F.G. 1990. Teknologi Pengolahan Rumput Laut. Sinar Pustaka Harapan. Jakarta. 